\title{
New Records of Philippine Mosses in Two Mountain Sites of Camiguin Island, Mindanao
}

\author{
LESLEY CASAS LUBOS \\ ORCID No. 0000-0002-8761-3680 \\ lesleyclubos@liceo.edu.ph \\ Liceo Mindanao Center for Biodiversity and Conservation \\ Research and Publication Office \\ RN Pealez Boulevard, Kauswagan \\ Cagayan de Oro City, Philippines
}

\begin{abstract}
Bryophytes are a group of plants that include mosses, liverworts and hornworts. Mosses may be small, but they may also be as complex as flowering plants. They have stems with leaves, and there is just about as much variation in the form and size of these plants as there is in the flowering plants. The objective of the study was to identify the collected species of mosses found on selected mountains in Camiguin Island. Survey of mosses was conducted in Mt. Hibok-hibok and Mt. Timpoong, Camiguin Province, Philippines. As a result, the author identified 37 species of Camiguin mosses belonging to 24 genera of which two species are new records for the Philippines namely: Radulina lavei-hamata (Dix.) B. C. Tan and Clastobryopsis planula (Mitt.) M. Fleisch. Ex-situ and in-situ conservation and protection must be continuously done of the two Mountains.
\end{abstract}

Keywords: mosses, new record, Camiguin, Mt. Hibok-hibok, Mt.Timpoong, Philippines 


\section{INTRODUCTION}

Camiguin is an island province of the Philippines located in the Bohol Sea, about 10 kilometres $(6.2 \mathrm{mi})$ off the northern coast of Mindanao. It is politically part of the Northern Mindanao Region of the country and formerly a part of Misamis Oriental province. Camiguin is the second-smallest province in the country both in population and land area after Batanes. Mambajao is the capital of the province and its largest municipality both in area and population (Philippine Standard Geographic Code Interactive, 2012).

The island has several volcanoes that are popular hiking destination for which a permit from the DENR office in Mambajao is required. Mt. Hibokhibok $\left(9^{\circ} 12^{\prime} 4^{\prime \prime} \mathrm{N} 124^{\circ} 40^{\prime} 31^{\prime \prime} \mathrm{E}\right)$ is the northernmost and the only active volcanic vents in Camiguin with an elevation of 1,332 masl (4,370 ft) and a base diameter of 10 kilometres $(6.2 \mathrm{mi})$ and the Mt. Timpoong is the largest mountain in Camiguin. It is composed of several domes the tallest of which is the Timpoong Peak $\left(9^{\circ} 10^{\prime} 42.3^{\prime \prime} \mathrm{N} 124^{\circ} 43^{\prime} 40.4\right.$ 'E), also the highest in Camiguin at $5,294 \mathrm{ft}$ (1,614 masl) (Philippine Institute of Volcanology and Seismology, 2012)

Tan, Schwarz, and Lubos (2000) reported sixteen new records of Philippine species collected from Mindanao, and additionally, five taxa of Mindanao mosses that present noteworthy local range extensions. Of the 16 new records of Philippine mosses, two are primarily continental Asiatic in range, seven are widespread Malesian species, two are Bornean-Mindanao endemic, and five are Australasian/Oceanian taxa reaching the Philippines (mainly Mindanao).

To date, Mindanao Island has an increasing number of genera and species of mosses due to increasing number of collections and interest in the study of Philippine muscology. According to Tan (2008) moss flora of Mindanao has a strong southern and Australasian influence compared to those in other large islands in the country .

Mindanao was cited as an important island, albeit with a still incompletely known flora, which may hold critically the key to a better understanding of the 
origin and evolution of the entire Philippine moss flora.

\section{OBJECTIVES OF THE STUDY}

The objective of the study was to identify the collected species of mosses found on selected mountains in Camiguin Island.

\section{MATERIALS AND METHODS}

\section{Survey and Collection}

Survey of mosses was conducted in Mt. Hibok-hibok (Plate 2) and Mt. Timpoong (Plate 3), Camiguin Province, Philippines (Plate 1 and Fig. 1). Representative specimens of mosses were collected at $10 \mathrm{~m}$ on each side of the trail from the base to the upper portion of the three selected areas using the alpha- taxonomy method.

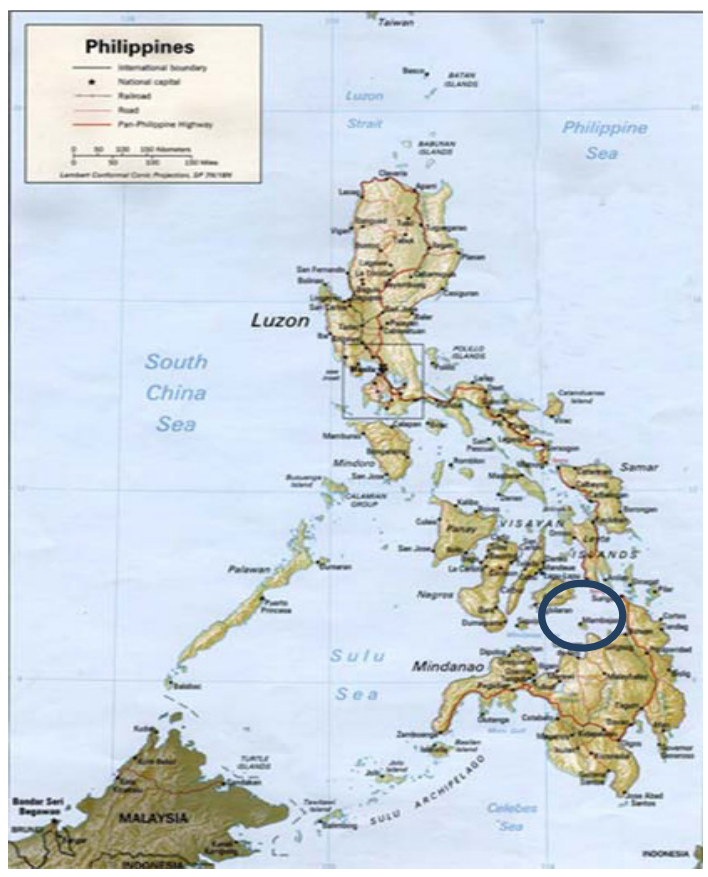

Plate 1. Map of the Philippines (inset-Camiguin) 


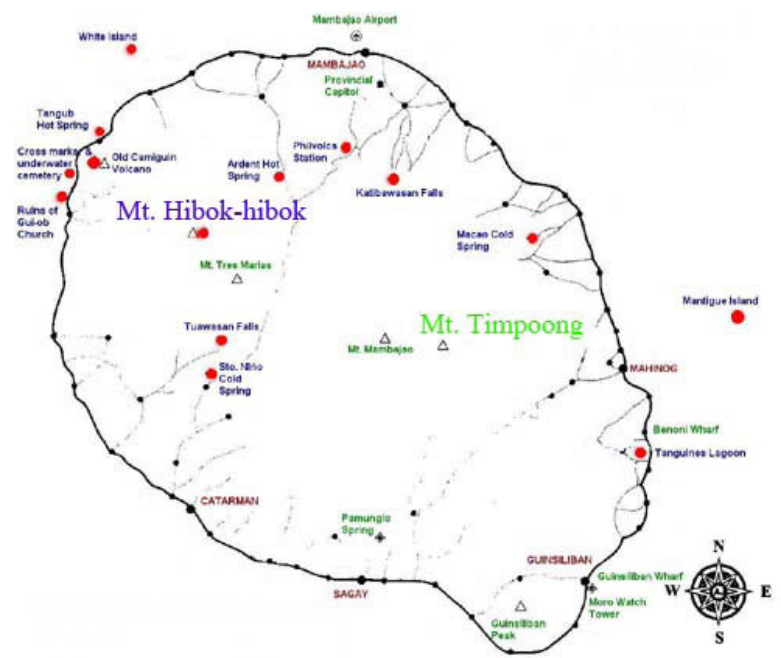

Figure 1. Map of Mountains in Camiguin

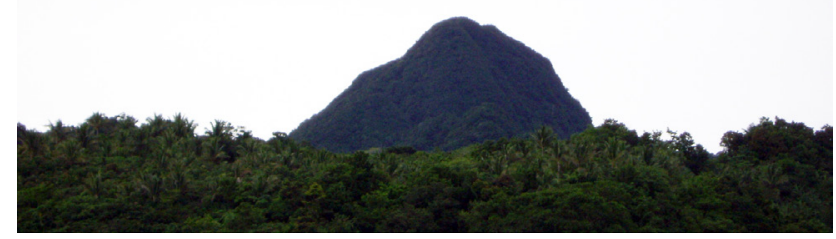

Plate 2. Mt. Timpoong, Camiguin 


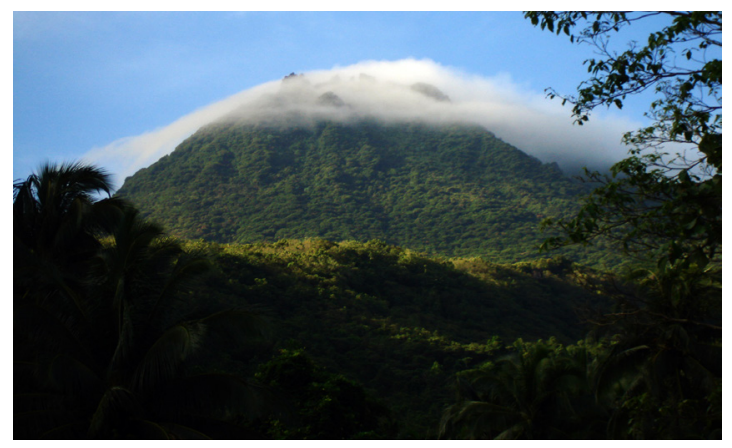

Plate 3. Mt. Hibok-hibok, Camiguin

\section{Classification and Identification}

The specimens collected were classified and identified using the taxonomic keys of Bartram (1939) and other related literatures. Morphological characters of the leaf (leaf arrangement, midrib, base, apex, margin, cells, shape) and sporophyte (size, shape, texture of capsule and seta, number of teeth) were used to identify the species( Plate 4).

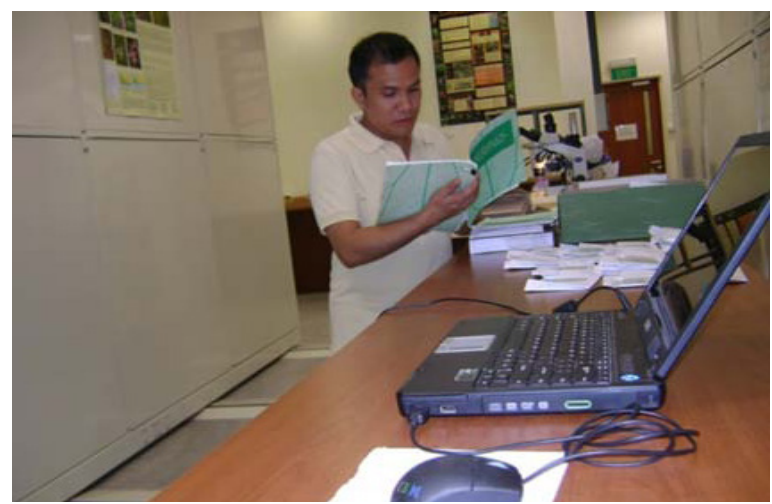

Plate 4. The researcher identifying and classifying the collected specimens

\section{Photographs}

A camera was used for documentation. Handlens (Plate 5), Stereomicroscope, trinocular microscope, and dissecting microscope (Plate 6) were also used to identify and classify the species of mosses. 


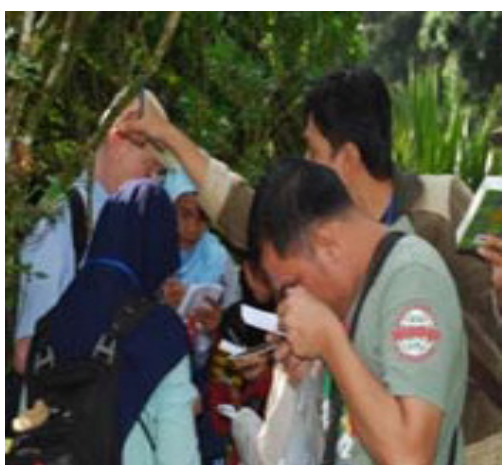

Plate 5. The author identifying the specimen using handlens.

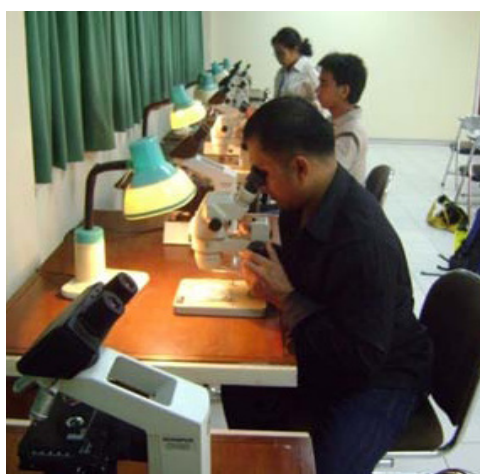

Plate 6. The author identifying the specimen using microscope.

\section{Preparation of Herbarium specimens}

The collected specimens of mosses were placed in a plastic bag or ziplock, labelled with the following data: collection number, name of collector, altitude, name of the mountain, date of collection, and associated habitats. This was then air-dried and placed in a standard packet and properly labeled for herbarium vouchers (Plate 7).

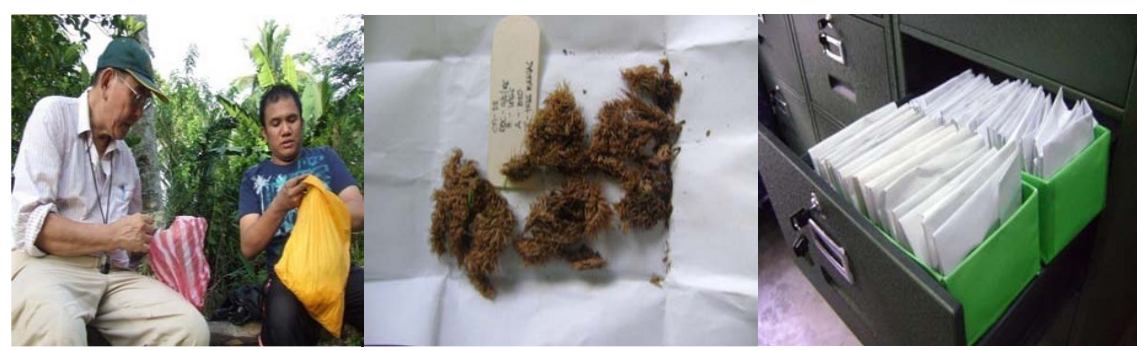

Plate 7. The researcher preparing the herbarium specimens.

\section{Assessment of Conservation Status}

A New Annotated Checklist of Iwatsuki and Tan (1991) print scientific journals and on-line journals (Plate 8) were used to determine the status of the collected specimens. Assessment of conservation status of the species, whether new record in the Philippines, new in Mindanao, new in terms of locality, rare, and widespread was made. 


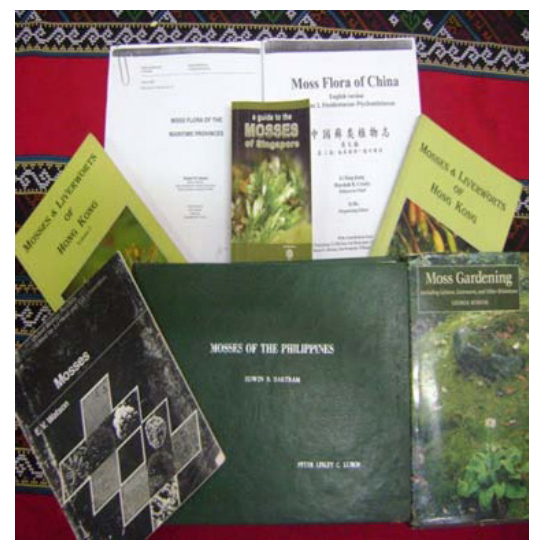

Plate 8. References used for the assessment of conservation status of the species.

\section{RESULTS AND DISCUSSION}

As a result, the author identified 37 species of Camiguin mosses belonging to 24 genera of which two species are new records for the Philippines namely: Radulina lavei-hamata (Dix.) B. C. Tan and Clastobryopsis planula (Mitt.) M. Fleisch.

Table 1. Species, Mountains, and Status of Bryophytes found in the Philippines

\begin{tabular}{|l|l|l|}
\hline Species & Mountain found & Status \\
\hline $\begin{array}{l}\text { Radulina. Lavei-hamata (Dix.) B. } \\
\text { C. Tan }\end{array}$ & Mt. Timpoong & New Record in the Philippines \\
\hline $\begin{array}{l}\text { Clastobryopsis planula (Mitt.) M. } \\
\text { Fleisch }\end{array}$ & Mt. Hibok-hibok & New Record in the Philippines \\
\hline
\end{tabular}

Genus Radulina W.R. Buck \& B.C. Tan

This distinctive genus is the former section Thelidium or Trichosteleum, which was segregated on the basis of pluripapillose leaf cells (Buck \& Tan 1989). 
Radulina probably has 3-4 species across Malesia and Oceania, including one from Society Islands, i.e., $R$. orthophylla (Tan et al. 2005). Three species are reported from western Melanesia.

Radulina laevi-hamata (Dix.) B.C. Tan, T. J. Kop. \& D.H. Norris

Distribution: Known only from Papua New Guinea.

Now Recorded in the Philippines: Mt. Timpoong, Camiguin Province 2012-2013

Genus Clastobryopsis Fleisch.

The genus Clastobryopsis was combined with Aptychella (Broth.) Herz. by Fleischer (1915-1922), Tixier (1977) suggested that the Asiatic species with perforate and densely papillose exostomial teeth be placed separately in Clastobryopsis. They modified the concept of Clastobryopsis sensu Tixier (1977) to include, in addition, a few morphologically related Asiatic species without perforate peristomial teeth. Three species of Clastobryopsis are reported from China (Redfearn et a1.1996).

Clastobryopsis planula (Mitt.) M. Fleisch

Distribution: Himalaya, India, China.

Now recorded in the Philippines: Mt. Hibok-hibok, Camiguin Province 2012-2013

\section{CONCLUSION}

Mountains Hibok-hibok and Timpoong in Camiguin Province are found to have Two New Records of Philippine mosses.

\section{RECOMMENDATIONS}

1. Ex-situ and in-situ conservation and protection must be continuously done in Mt.Hibok-hibok and Mt.Timpoong in Camiguin Province;

2. the Locals must be informed about the existence of the two new records of Philippine mosses; and 
3. further studies should be conducted in other mountains in Camiguin Island.

\section{ACKNOWLEDGMENTS}

The author wishes to thank Dr. Benito C. Tan for helping in the identification of the specimens and the local people and the officials in Camiguin Province especially to Governor Jurdin Jesus M. Romualdo. The study was funded by Liceo de Cagayan University, Cagayan de Oro City, Philippines.

\section{LITERATURE CITED}

Bartram, E.B.

1939 Mosses of the Philippines. Philippine Journal of Science. 68:1- 425.

Gradstein, Robert, Yong Kein-Thai, Monica Suleiman, Afiatri Putrika, Eny Yuniati, Fadzilah Ag kanak, Fuad Bahrul Ulum, Indah Wahyuni, Kanjana Wongkuna, Lesley Lubos, Luong ThiemTam, Mika Rizki Puspaningrum, Mohd Rawiyani,Pg.Hj. Serudin, Musyarofah Zuhri, $\mathrm{Ng}$ Aik Min, Nurlisma Junita, Nursahara Pasaribu, and Soonthree Kornochalert.

2010 Bryophytes of Mt. Patuha, West Java, Indonesia .Reinwardtia.Vol 13, No 2, pp: $107-123$.

Hall, R.

1998 The plate tectonics of Cenozoic SEAsia and the distribution of land and sea,pp. 99-131.

In: R. Hall \& J. D. Holloway (eds.), Biogeography and Geological Evolution of SE Asia. Backhuys Publisher,Leiden.

Lubos, Lesley C.

2000 Taxonomy, Species Richness and Distribution of Mosses in Selected Mountains in Mindanao. 
Lubos, Lesley C.

2010 Species Richness, Distribution, and Status of Mosses in Selected Mountains in Mindanao, Philippines. Asian Journal of Biodiversity. 1 (1): 63-82.ISI.

Philippine Institute of Volcanology and Seismology. 2012

Philippine Standard Geographic Code Interactive. 2012

So, M.L.

1995 Mosses and Liverworts of Hong Kong: Vol. 1. Hongkong: Heavenly People Depot.

Tan, B. C.

1984 A reconsideration of the affinity of Philippine moss flora. 3. Hattori Bot. Lab. 55: 13-22.

Tan, B. C.

1992 Philippine muscology (1979-1989).In: T. Koponen and J. Hyvönen (eds.).Proceedings of the Congress of East Asiatic Bryology, Helsinki, August 12-19, 1990. Bryobrothera 1: 137- 141.

Tan, B. C.

1994 The bryophytes of Sabah (North Borneo) with special reference to the BRYOTROP transect of Mount Kinabalu. XIX. The genus Acroporium (Sematophyllaceae, Musci) in Borneo, with notes on species of Java and the Philippines. Willdnowia 24: 255-294.

Tan, B. C.

1998 Noteworthy disjunctive patterns of Malesian mosses, pp. 235- 241. In: R. Hall \& J. D. Holloway (eds.), Biogeography and Geological Evolution of SE Asia. Backhuys Publisher, Leiden. 
Tan, B. Ho, B. Lim, Y.H.

2008 A Guide to the Mosses of Singapore. Science Center, Singapore.

Tan, B. C. and Z. Iwatsuki.

1991 A new annotated Philippine moss checklist. Harvard Papers Bot. 3: 1

Tan, B.C., L.C. Lubos, and Uwe Schwarz.

2000 New and Biogeographically Noteworthy Records of Philippine Mosses from Mindanao Island. Tropical Bryology 18.pp.27-38,

Tan, B.C., Timo koponen and Daniel H. Norris

2007 Bryophyte Flora of the Huon Peninsula, Papua New Guinea.LXX. Sematophyllaceae (Musci) 1. Acanthorrhynchium, Acroporium, clastobryophilum, Pseudopiloecium, Radulina, and Trichosteleum.Ann. Bot. Fennici 44:35-78.

Tan, B.C., and Yu Jia.

1999 A Preliminary Revision of Chinese Sematophyllaceae.J.Hattori Bot. Lab.no.86:1-70.

Zhu, R.L. and So, M.L.

1995 Mosses and Liverworts of Hong Kong: Vol. 2. Hong Kong: Heavenly People Depot.

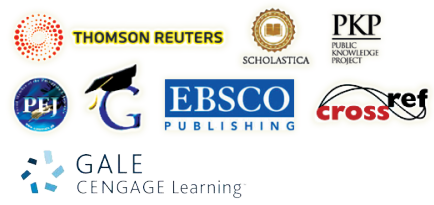

